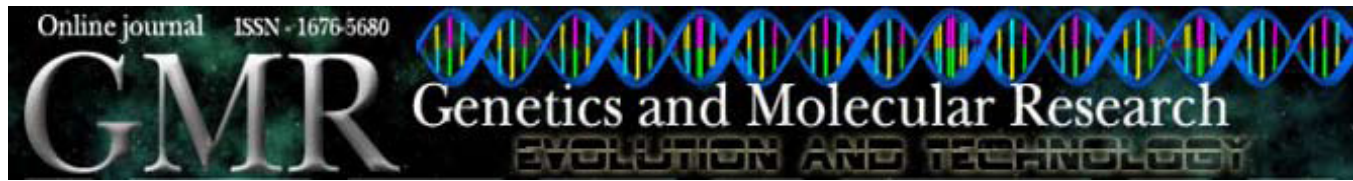

Homage

\title{
Nagib Nassar, Geneticist, Botanist and Plant Breeder, Celebrates 50 Years of Teaching and Research
}

My love of plants goes back to very early in life, at the age of 12 onwards, planting shrubs in our home garden, following their growth and thinking about them constantly. They were my enjoyment, my hobby and my entertainment. At the university, I began to examine flowers and learn about their systematics. This opened the door for me to the very exciting world of botany in which I live to this day. For my Ph.D. study, I applied cytogenetic data to the taxonomy of Chenopodiaceae in what is now known as cytotaxonomy.

My fifty years of teaching were divided into 15 years with Cairo University from 1958 to 1974 and 35 years with the University of Brasília. This multi-cultural experience exposed me to a broad range of learning styles and allowed me to acquire a number of different teaching methods. At Cairo University, I taught horticulture and conservation of plant genetic resources. At Brasília, I taught plant breeding, organic evolution, evolution of cultivated plants, basic cytogenetics, cytogenetic methods and techniques, economic botany, plant breeding of perennial crops, and botany of cassava to both undergraduate and graduate students. I taught several of these courses at the federal universities of Goiás, Viçosa, Rio Grande do Sul, Brasília, Feira de Santana and Costa Rica and Bern University in Switzerland.

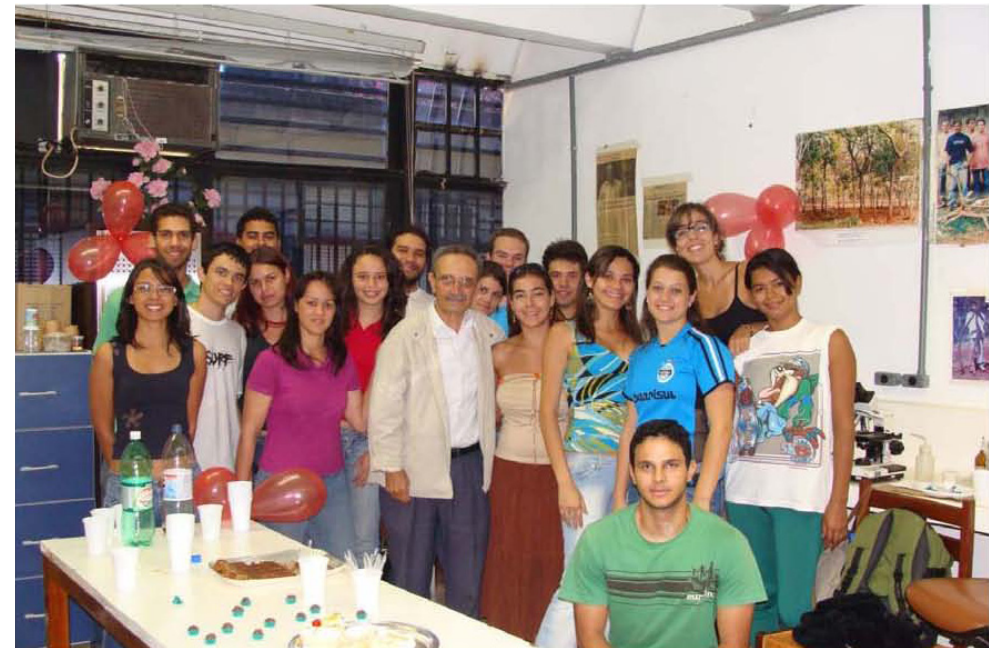

Figure 1. Professor Nassar with students at the University of Brasília. 
My teaching experience has been very rewarding. It is from my experience with teaching that I have gained my greatest strength. Teaching for me was like composing a piece of music, and for years and years I had the aspirations of being admired by my students the same way students admire their idols such as musicians and artists. I always tried to create a strong friendship with my students from the moment they joined my class up to their graduation.

In 1975, I began my first mission to collect wild Manihot species in Brazil on behalf of IITA (International Institute of Tropical Agriculture). I was at that time a visiting scientist sponsored by the Brazilian Ministry of Foreign Relations stationed at the University of São Paulo. The financial support from IITA was so small that it did not permit me to hire any assistants to accompany me on my collection trips. By the end of four months, I was able to collect seeds of more than 20 wild species native to 8 Brazilian states, collecting wild species for IITA, which encouraged the Canadian International Development Research Center (IDRC) to help me plant and propagate a living collection at the Universidade de Brasília. My goal was not only to propagate and conserve them but to use them for crop improvement. Five years later, I was able to provide IITA with hybrid seed that gave rise to cultivars now planted on about 4 million hectares in Nigeria making it the top-ranking producer of cassava all over the world. "Your breeding approach shows the benefits of preserving biodiversity..." "of enhancing cassava germplasm...[and] new methods for the propagation of this crop...." said Rodomiro Ortiz, director and deputy director general of IITA.

See http://www.geneconserve.pro.br/iita2.gif

And http://www.geneconserve.pro.br/decades_of_cassava.pdf

The success of my work on wild Manihot in the 1970s prompted the International Board of Genetic Resources (IBPGR) to delegate me for a mission of 3 months collecting wild Manihot native to Mexico. Since the 1980s, I continued working on cassava and for the last decade I have concentrated on the embryology of this group. This led me to the most important discovery of apomixis and transfer of their genes to cultivated forms, producing the first apomictic cultivars of this crop. This shows how much botany can serve breeding programs and botanists.

Most recently, I was involved in developing cassava hybrids that are rich in protein. The first such hybrid was bred by me early in the 1980s. We can now release hybrids that are very productive and contain high protein and essential amino acids.

Conserving wild cassava, Manihot species native to Brazil and Mexico was the most fascinating work in my career, which began 35 years ago. My knowledge of the botany of this group enabled me to collect and conserve them and manipulate them for crop improvement. I emphasize to my students that knowing the botany of a certain crop is the principal step towards an improvement program or breeding it with cultivated forms. Knowing the habitat in which it grows provides clues to important characteristics that may be incorporated into the cultivar. Breeders must also understand the reproductive system of his crop to choose adequate methods of breeding (See list of publications on this subject).

Nagib Nassar; Departamento de Genética e Morfologia. Instituto de Ciências Biológicas, Universidade de Brasília, Campus Universitário Darcy Ribeiro, Asa Norte, 70910-900 Brasília, DF, Brasil

Phone: (*55.61) 3307.2169. Fax: (*55.61) 3272.0003. E-mail: nagnassah@rudah.com.br 


\section{LIST OF PUBLICATIONS ON THIS SUBJECT}

Buso GS, Carvalho LJ and Nassar NMA (1994). Analysis of Genetic Relationships Among Manihot Interspecific Hybrids and their Paternal Species Using RAPD Assay. In: The Cassava Biotechnology Network. Proceedings of the 2nd International Scientific Meeting of CBN, Borgor, 101-104.

Costa LR, Nassar NMA and Perim S (1984). Padrão de crescimento de raízes e partes aéreas da mandioca, Manihot esculenta Crantz. Turrialba 34: 530-531.

Gratapaglia DE, Nassar NMA and Dianese J (1987). Biossistemática de espécies brasileiras do gênero Manihot baseada em padrões de proteína da semente. Cienc. Cult. 39: 294-300.

Grattapaglia D, Silva CCE and Nassar NMA (1996). Strict maternal inheritance of RAPD fingerprints confirms apomixis in cassava (Manihot esculenta Crantz). Can. J. Plant Sci. 76: 379-382.

Nassar NMA (1978a). Conservation of the genetic resources of Cassava (Manihot esculenta) - determination of wildspecies localities with emphasis on probable origin. Econ. Bot. 32: 311-320.

Nassar NMA (1978b). Genetic resources of cassava - Chromosome behavior in some wild Manihot species. Indian J. Genet. Plant Breed. 38: 135-137.

Nassar NMA (1978d). Microcenters of wild cassava, Manihot ssp diversity in central Brazil. Turrialba 28: 345-347.

Nassar NMA (1978e). Some further species of Manihot with potential value to cassava breeding. Can. J. Plant Sci. 58: 915-916.

Nassar NMA (1978f). Wild Manihot species of central Brazil for cassava breeding. Can. J. Plant Sci. 58: 257-261.

Nassar NMA (1979a). A study of the collection and maintenance of the germplasm of wild cassavas, Manihot spp. Turrialba 29: 221-224.

Nassar NMA (1979b). Three Brazilian Manihot species with tolerance to stress conditions. Can. J. Plant Sci. 59: 553-555.

Nassar NMA (1980a). Attempts to hybridize wild Manihot species with cassava. Econ. Bot. 34: 13-15.

Nassar Nagib MA (1980b). The need for germplasm conservation in wild cassava. Indian J. Genet. Plant Breed. 39: 465-470.

Nassar NMA (1981). Interspecific Manihot grafting: a way to maintain wild cassavas, Manihot $\mathrm{sp}$. in living collections. Cienc. Cult. 33: 414-416.

Nassar Nagib MA (1982). Collecting wild cassava in Brazil. Indian J. Genet. Plant Breed. 42: 405-411.

Nassar NMA (1983). A quebra da dormência da semente das espécies selvagens da mandioca, Manihot spp. Cienc. Cult. 35: 630-632.

Nassar NMA (1984). Natural hybrids between Manihot reptans Pax and Manihot alutacea Rogers and Appan. Can. J. Plant Sci. 64: 423-425.

Nassar NMA (1985). Manihot neusana Nassar: A new species native to Paraná, Brazil. Can. J. Plant Sci. 65: 1097-1100.

Nassar NMA (1986c). Genetic variation of wild Manihot species native to Brazil and its potential for cassava improvement. Field Crops Res. 13: 177-184.

Nassar NMA (1989). Broadening the genetic base of cassava, Manihot esculenta Crantz, by interspecific hybridization. Can. J. Plant Sci. 69: 1071-1073.

Nassar NMA (1992). Cassava in South America: a plant breeder's viewpoint. Indian J. Genet. Plant Breed. 52: 230-237.

Nassar NMA (1992). Production of triploid cassava, Manihot esculenta Crantz by hybrid diploid gametes. Field Crops Res. 30: 173-182.

Nassar NMA (1994). Selection and development of cassava apomictic clones. Cienc. Cult. 41: 168-171.

Nassar NMA (1994). Relationship between Manihot species. A Review. In: Proceedings of the 2nd International Scientific Meeting of the Cassava Biotechnology Network, Borgor, 99-100.

Nassar NMA (1997). Development of cassava interspecific hybrids for savanna conditions. J. Root Crops 22: 9-17.

Nassar NMA (2000). Cassava, Manihot esculenta Crantz, genetic resources: their collection, evaluation, and manipulation. Adv. Agron. 69: 179-230.

Nassar NMA (2000). Cytogenetics and evolution of cassava (Manihot esculenta Crantz). Genet. Mol. Biol. 23: 10031014.

Nassar NMA (2000). Wild cassava, Manihot spp.: Biology and potentialities for genetic improvement. Genet. Mol. Biol. 23: $201-212$.

Nassar NMA (2001). The nature of apomixis in cassava (Manihot esculentum, Crantz). Hereditas 134: 185-187.

Nassar NMA (2003a). Cassava, Manihot esculenta Crantz and wild relatives: Their relationship and evolution. Genet. Res. Crop Evol. 48: 429-436.

Nassar NMA (2003b). UnB 033. An interesting cassava hybrid. Ceres 50: 22-26.

Nassar NM (2003c). Cassava, Manihot esculenta Crantz genetic resources: VI. Anatomy of a diversity center. Genet. Mol. Res. 2: 214-222.

Nassar NM (2003d). Gene flow between cassava, Manihot esculenta Crantz, and wild relatives. Genet. Mol. Res. 2: 334-347. 
Nassar NMA (2004a). Polyploidy, chimeras and fertility of interspecific cassava hybrids. Indian J. Genet. Plant Breed. 64: $132-134$.

Nassar NMA (2004b). Cassava: Some considerations on its ecology and improvement. J. Food Agric. Environ. 2: 167-173. Nassar NMA (2005a). Cassava genetic resources extinct in Brazil. Genet. Res. Crop Evol. 51: 1-8.

Nassar NMA (2005b). Microsatellite markers confirm high apomixis level in cassava inbred lines. Hereditas 142: 1-5.

Nassar NMA (2006). Are genetically modified crops compatible with sustainable agriculture? Genet. Mol. Res. 5: 91-92.

Nassar NMA (2006). Cassava genetic resources extinct everywhere in Brazil. Genet. Res. Crop Evol. 53: 975-983.

Nassar NMA (2006). Cassava in South America, Brazil's contribution and the lesson to be learned from India. Genet. Mol. Res. 5: 688-695.

Nassar NMA (2006). Chromosome doubling induces apomixis in a cassava x Manihot anomala hybrid. Hereditas 143: 246-248.

Nassar NMA (2006). The synthesis of a new cassava-derived species, Manihot vieiri Nassar. Genet. Mol. Res. 5: 536-541.

Nassar NMA (2006). Wild cassava species: How much contributed to the crop? Genet. Mol. Biol. 5: 419-420.

Nassar NMA (2007). Wild and indigenous cassava diversity: an untapped genetic resources. Genet. Res. Crop Evol. 54: 1-10.

Nassar NMA (2007). Cassava genetic resources and their utilization for breeding of the crop. Genet. Mol. Res. 6: 1151-1168.

Nassar NMA (2007). Cassava improvement: challenges and impact. J. Agric. Sci. 145: 1-9.

Nassar NMA (2007). Wild and indigenous cassava, Manihot esculenta Crantz diversity: an untapped genetic resource. Genet. Resour. Crop. Evol. 54: 1523-1530.

Nassar NMA (2008). Cassava wild species and their sustainable use. Gene Conserv. 8: 1855-1867.

Nassar NMA and Costa CP (1977). Tuber formation and protein content in some wild cassava (mandioca) species native of central Brazil. Experientia 33: 1304-1306.

Nassar NMA and Fichtner SS (1978c). Hydrocyanic acid content in some wild Manihot (cassava) species. Can. J. Plant Sci. 58: 577-578.

Nassar NMA and Dorea G (1982). Protein contents of cassava cultivars and its hybrid with Manihot species. Turrialba 32: 429-432.

Nassar NMA and O'Hair SK (1985). Variation among clones in relation to seed germination. Indian J. Genet. 45: 429-432.

Nassar NMA and Cardenas (1986). Collecting wild cassava in Northern Mexico. FAO/IBPGR Plant Genet. Resour. Newsl. 65: 29-30.

Nassar NMA and Grattapaglia D (1986e). Variabilidade de clones de mandioca em relação a fertilidade e aspectos morfológicos. Turrialba 36: 555-559.

Nassar NMA and Freitas M (1997). Prospects of polyploidizing cassava, Manihot esculenta Crantz, by unreduced microspores. Plant Breed. 116: 195-197.

Nassar NM and Collevatti RG (2005). Breeding cassava for apomixis. Genet. Mol. Res. 4: 710-715.

Nassar NMA and Marques AO (2006). Cassava leaves as a source of protein. Int. J. Food Agric. Environ. 4: 187-188.

Nassar NM and Sousa MV (2007). Amino acid profile in cassava and its interspecific hybrid. Genet. Mol. Res. 6: 192-197.

Nassar NMA and Ortiz R (2008). Cassava genetic resources: manipulation for crop improvement. Plant Breed. Rev. 31: 1-50.

Nassar NMA and Collevatti R (2008). Embryonic, meiotic and molecular analysis of apomictic cassava (Manihot esculenta Crantz). Gene Conserv. 7: 497-519.

Nassar NMA, da Silva JR and Vieira C (1985). Hibridação interespecífica entre mandioca e espécies silvestres de Manihot Adans. Cienc. Cult. 38: 1050-1055.

Nassar HN, Nassar NMA, Vieira C and Saraiva LS (1995). Cytogenetic behavior of the interspecific hybrid of Manihot neusana Nassar and Cassava, M. esculenta Crantz, and its backcross progeny. Can. J. Plant Sci. 75: 675-678.

Nassar NMA, Carvalho CG and Vieira C (1996). Overcoming crossing barriers between cassava, Manihot esculenta Crantz and a wild relative, M. pohlii Warwa. Braz. J. Genet. 19: 617-620.

Nassar NMA, Nassar HN, Carvalho CG and Vieira C (1996). Induction of a productive aneuploid in cassava, Manihot esculenta Crantz. Braz. J. Genet. 19: 123-125.

Nassar NMA, Vieira MAR, Vieira C and Gratapaglia D (1998). Evidence of apomixis in cassava (Manihot esculenta Crantz). Genet. Mol. Biol. 21: 527-530.

Nassar NMA, Vieira MA, Vieira C and Grattapaglia D (1998). A molecular and embryonic study of apomixis in cassava (Manihot esculenta Crantz). Euphytica 102: 9-13.

Nassar NMA, Dos Santos E and David SRO (2000). The transference of apomixis genes from Manihot neusana Nassar to cassava, M. esculenta Crantz. Hereditas 132: 167-170.

Nassar NMA, Vizzotto CS, Silva HL, Schvartz CA, et al. (2005). Potentiality of cassava cultivars as a source of carotenoids. J. Food Agric. Environ. 3: 33-35.

Nassar NMA, Kalkmann DC and Collevatti R (2006). Molecular analysis of apomixis in cassava. Genet. Mol. Res. 5: 487-492. 
Nassar NMA, Kalkmann D and Collevatti R (2007). A further study of microsatellite on apomixis in cassava. Hereditas 144: 181-184.

Nassar N, Vizzotto CS, Schwartz CA and Pires OR Jr (2007). Cassava diversity in Brazil: the case of carotenoid-rich landraces. Genet. Mol. Res. 6: 116-121.

Nassar NM, Graciano-Ribeiro D, Fernandes SD and Araujo PC (2008). Anatomical alterations due to polyploidy in cassava, Manihot esculenta Crantz. Genet. Mol. Res. 7: 276-283.

Nassar NM, Hashimoto DY and Fernandes SD (2008). Wild Manihot species: botanical aspects, geographic distribution and economic value. Genet. Mol. Res. 7: 16-28.

Nassar NMA, Hashimoto D and Gomes P (2008). Predicting Manihot species compatibility by molecular analysis. Gene Conserv. 7: 480-486.

Vasquez N and Nassar NMA (1994). Unreduced microspores in cassava, Manihot esculenta Crantz clones. Indian J. Genet. 52: 436-441. 